ČEDOMIR IVAKOVIĆ, Ph.D.

E-mail: cedomir.ivakovic@fpz.hr

University of Zagreb,

Faculty of Transport and Traffic Sciences

Vukelićeva 4, HR-10000 Zagreb, Republic of Croatia

RATKO STANKOVIĆ, Ph.D.

E-mail: stankovic.zagreb@transadria.hr

Transadria d.d., Robni terminali Žitnjak

Slavonska avenija 52, HR-10132 Zagreb,

Republic of Croatia

MARIO ŠAFRAN, Ph.D.

E-mail: mario.safran@fpz.hr

University of Zagreb,

Faculty of Transport and Traffic Sciences

Vukelićeva 4, HR-10000 Zagreb, Republic of Croatia
Distribution Logistics Original Scientific Paper Accepted: June 19, 2009 Approved: Mar. 19, 2010

\title{
OPTIMISATION OF DISTRIBUTION NETWORK APPLYING LOGISTIC OUTSOURCING
}

\begin{abstract}
The problem of forming the distribution network results from the need to harmonize the characteristics of efficiency and efficacy of the supply chain with the corporate competition strategy. In this sense the possibility of optimising the distribution network has been presented (on a mathematical model) by applying the logistic outsourcing. The optimisation has been carried out using MS Excel software tools Solver. The results of the analysis have shown that possibilities for the reduction of distribution costs need to be searched for primarily in the domain of transport, in the target segment of the distribution network. The improvement elements have been achieved by outsourcing part of the supply chain, i.e. by introducing the cross-docking system which is managed by the external supplier of the logistic services. Quantitative changes, apart from the redistribution of the traffic of logistic and distribution centres and the reduction of logistic costs, have been reflected also in the geographical arrangement of distribution. The logistic outsourcing had dominant impact on the formation of the distribution network.
\end{abstract}

\section{KEY WORDS}

distribution network, optimisation, logistic outsourcing

\section{INTRODUCTION}

For the perception of the customers about the product or service, the most important phase of the supply chain is the distribution, since it represents a link to the customers, through which they experience and assess the functioning of the supply chain as a whole [1]. The formation of the distribution network consists basically of determining the number and lo- cations of logistics and distribution centres (LDCs), their catchment zone, function, capacity and operation technology [2]. This is the basis of determining the transport method (transport means, transport route, dynamics,.....) and the transport technology. The distribution network is formed according to the set requirements of efficacy and efficiency of the supply chain, in compliance with the corporate competition strategy, and the quality of the solution obtained in this way can be checked by the simulation on the mathematical model [3]. The analysis of the simulation results can provide identification of the elements that need to be optimised in order to rationalize the logistic costs, and this will be presented on the model of actual distribution network with the cross-docking system.

\section{DEFINING THE LOGISTIC PROBLEM}

The distributer's task is to satisfy the demand for certain product on their market, with minimal distribution costs. The distributer buys the goods based on CIF parity [4] of the European port. This refers to the product that is manufactured in factories in the Far East, and delivered from there via sea container transport to the port of Hamburg (northern route), i.e. alternatively to the port of Koper and/or Rijeka (southern route). The containers with goods are then transported using surface transport to LDCs in inland where these are emptied (unloaded), and the empty containers are then returned to the port. The factories deliver the product that is not yet ready to be delivered to the customer, and has to undergo finishing operations at the 


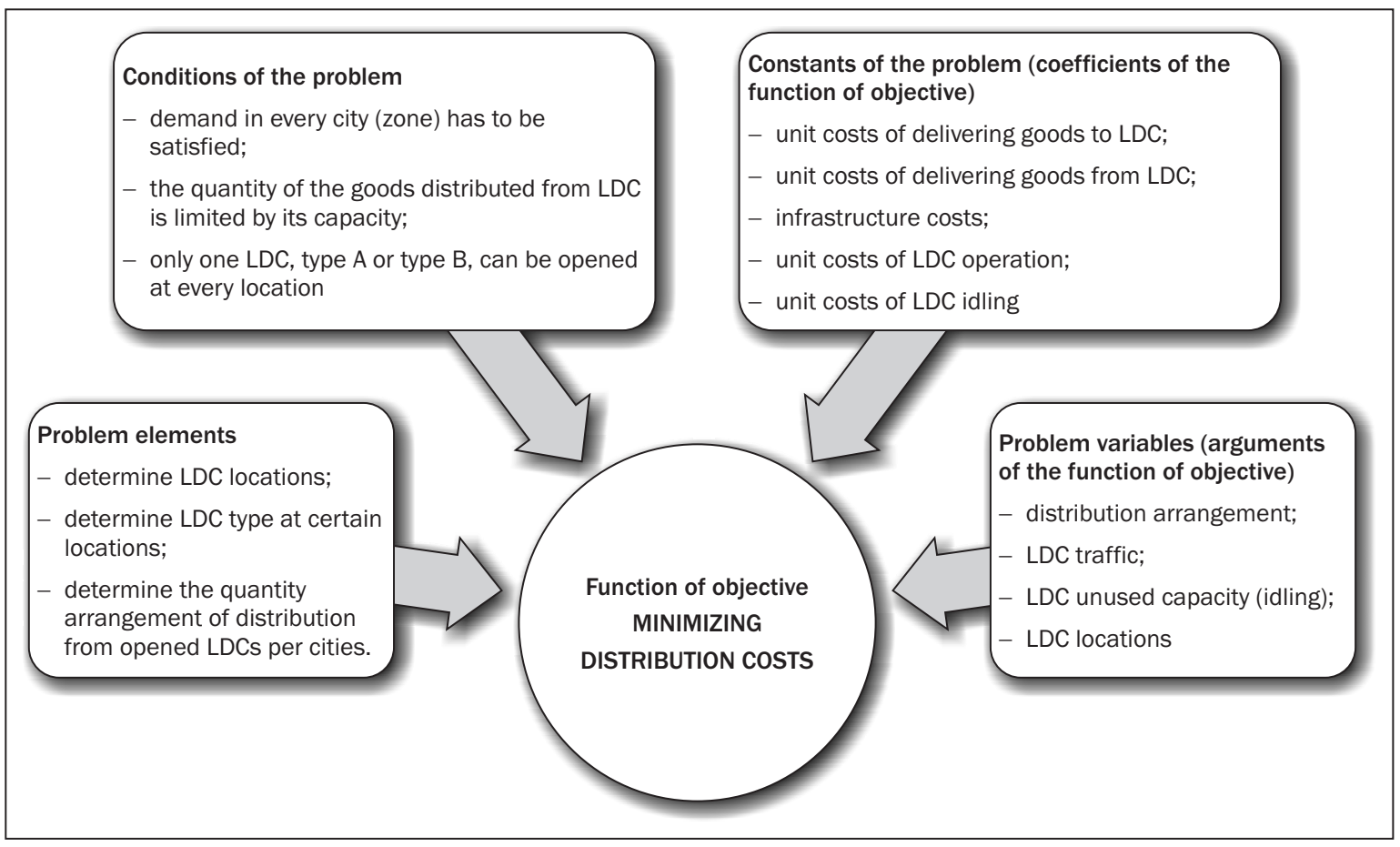

Scheme 2 - Task problem

LDC of the destination (sorting, control, packaging into commercial packing materials, labelling, ...). After that the goods are delivered to the points of sale where they are available to the customers. The task problem is presented in Scheme 2.

The problem can be solved if the total distribution capacity of the network (sum of individual LDC capacities) is greater than or equal to the total market demand (sum of the demands of individual cities with their catchment zones). The problem solubility condition is expressed by the following mathematical expression:

Let: $K=\sum_{i=1}^{n} k_{i}$ and $P=\sum_{j=1}^{m} p_{j}$ where:

$n=$ total number of open LDCs, $n_{\max }=4$;

$K=$ total distribution capacity;

$p_{j}=$ demand in city $j$;

$k_{i}=$ LDC capacity at location $i$;

$m=$ total number of cities to be supplied;

$P=$ total market demand;

The problem can be solved if: $K \geq P$

\subsection{Mathematical model}

The mathematical model of the set task that encompasses all the elements of the problem is expressed by the following mathematical structure:

Function of objective:

$\min \sum_{i=1}^{n} o_{i} \cdot\left[f t_{i}+r_{i}\left(v t_{i}+d_{i}\right)+t v_{i} \cdot v_{i}\right]+\sum_{i=1}^{n} \sum_{j=1}^{m} t_{i j} \cdot q_{i j}$ under conditions:

$p_{j}-\sum_{i=1}^{n} q_{i j}=0 \quad$ for every $\quad j=1, \ldots, m$

$k_{i} \cdot o_{i}-\sum_{j=1}^{m} q_{i j} \geq 0 \quad$ for every $\quad i=1, \ldots, n$

$o_{i} \in\{0,1\} \quad$ for every $i=1, \ldots, n$

and simplification:

$r_{i} \cdot o_{i}=\sum_{j=1}^{m} q_{i j} \quad$ for every $\quad i=1, \ldots, n$

where:

$o_{i}=$ location variable, assumes value 1 if LDC is open at location $i$, i.e. 0 if LDC is not open at location $i$, binary variable $(0,1)$;

$\mathrm{ft}_{i}=$ fixed cost of LDC at location $i$, constant (€/month);

$r_{i}=$ realised turnover of LDC at location $i$, continuous variable (palette);

$v t_{i}=$ unit variable cost of LDC at location $i$, constant (€/palette);

$d_{i}=$ unit cost of goods delivery from the port to LDC at location $i$, constant ( $€ /$ palette);

$t v_{i}=$ unit cost of capacity excess of LDC at location $i$, constant ( $€ /$ palette);

$v_{i}=$ capacity excess of LDC at location $i$, continuous variable (palette);

$n=$ total number of open LDCs, $n_{\max }=4$;

$m=$ total number of cities to be supplied, $m=9$; 
$t_{i j}=$ unit transport cost from LDC at location $i$ to point of sale point in city $j$, constant (€/palette);

$q_{i j}=$ quantity of goods delivered from LDC at location $i$ in city $j$, continuous variable (palette).

$p_{j}=$ demand in city $j$, constant (palette/month);

$k_{i}=$ capacity of LDC at location $i$, constant (palette/month).

For solving the problem of the set logistic task the following properties of this mathematical model should be noted:

1. Model has only one function of objective.

2. There are exclusively relations between the values of the function of objective and its arguments (model variables), whereas the arguments of the function are not interdependent, and their effects are summed.

3. Relations between the values of the function of objective and its arguments are linear (coefficients of function of objective are constants of the model), i.e. the unit costs are the same for all the values of the realized traffic.

4. The model variables are continuous, i.e. can assume any non-negative integer value ${ }^{1}$, with the exception of the location variable, which is binary.

\subsection{SOLUTION OF THE LOGISTIC PROBLEM}

The solution of the distribution network, obtained by the application of MS Excel software tools Solver on the mathematical model is graphically presented in Figure 1. Three LDCs have been opened:

1. type A in Prague, to supply the Prague market; the goods are transported via the Port of Hamburg;

2. type B in Munich, to supply the markets of Munich, Stuttgart, Nurnberg, and Vienna; the goods are transported via the Port of Hamburg;

3. type B in Zagreb, to supply the markets of Zagreb, Ljubljana, Vienna, Bratislava and Budapest; the goods are transported via the Port of Rijeka.

\subsection{Analysis of distribution network solution}

The results of the analysis carried out (cf. Table 1) show that the transport costs account for the largest share in the costs of distribution (80\%), which means that possibilities for the reduction of logistic costs, i.e. optimization of the distribution network should be primarily looked for in the domain of transport, in the segment of the distribution network which in the traffic sense is encircled by the Munich - Vienna - Bratislava - Budapest - Zagreb - Ljubljana - Munich line (cf. Figure 1).

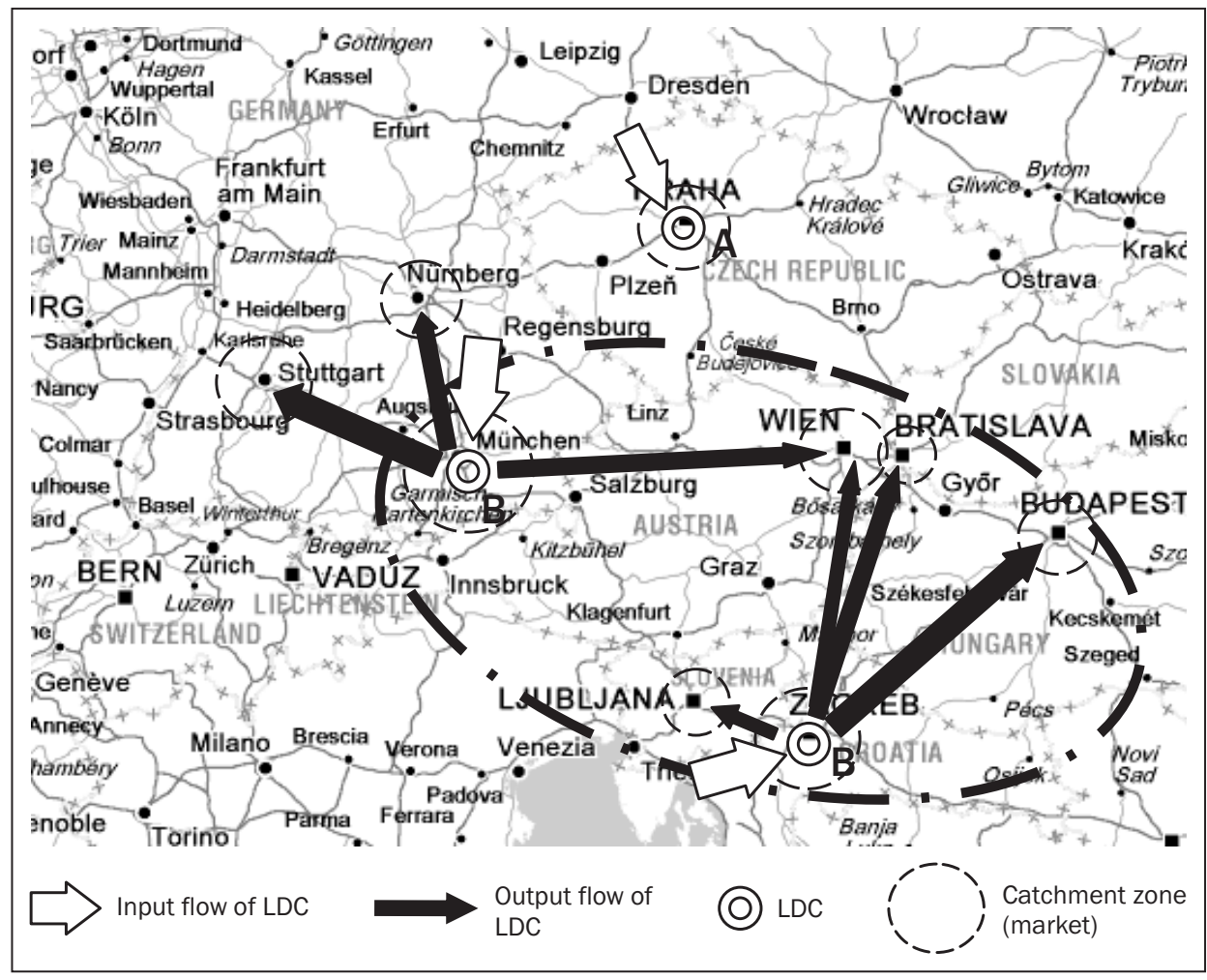

Figure 1 - Graphical presentation of the distribution network solution

Source: developed by the authors using a car map as model, URL: http//www.viamichelin.com 
Table 1 - Analysis of the distribution network solution

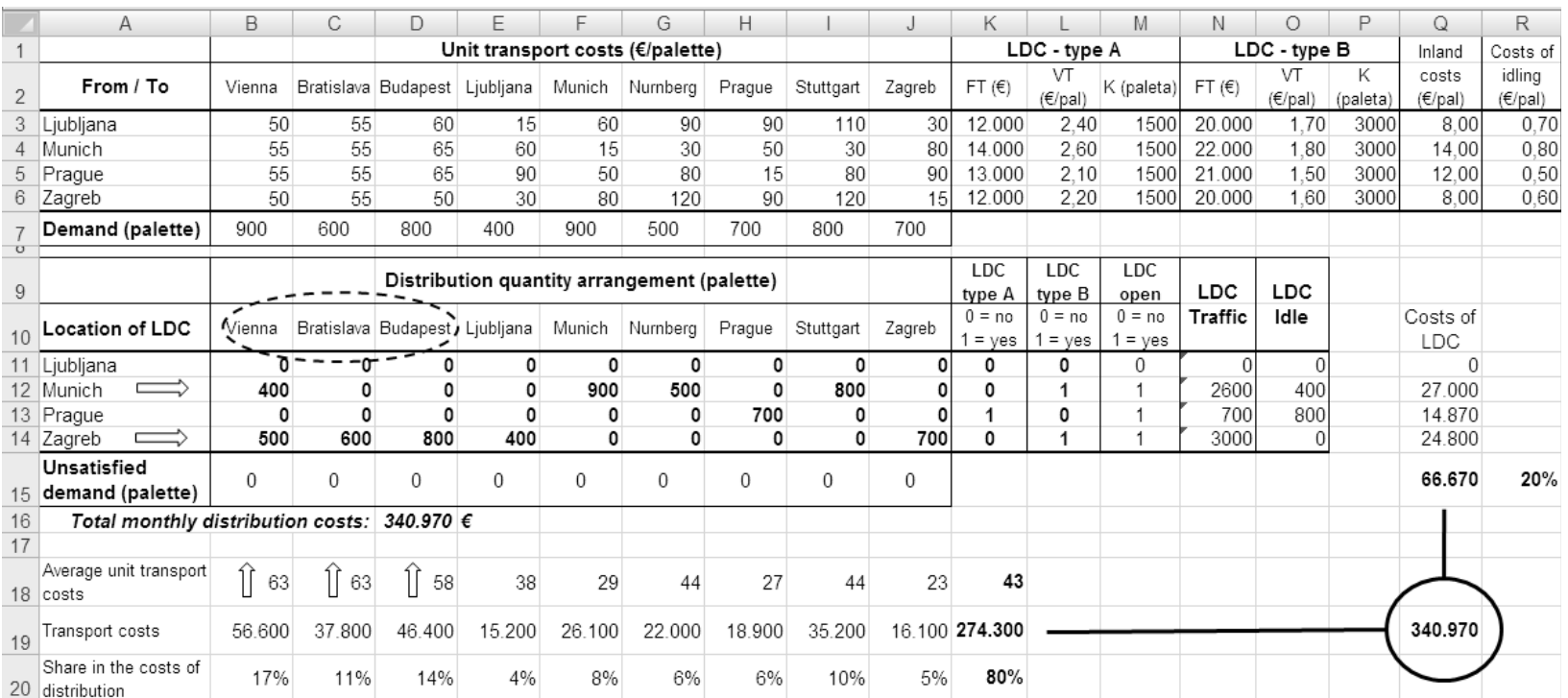

\section{IMPLEMENTATION OF LOGISTIC OUTSOURCING}

Logistic outsourcing has been applied to the distribution network by introducing the cross-docking system that is managed by 3PL operator ${ }^{2}$. Cross-docking can be defined as a continuous flow of goods through LDC, from the function of receiving to the function of dispatch, which eliminates the need for conventional warehousing [5]. The primary role of the warehouse is the coordination of incoming and outgoing flows, and not the accommodation and storage of goods ${ }^{3}$.

\subsection{Cross-docking system functioning}

The functioning of the cross-docking system is based on shifting the focus from supply to demand [6].
Every supplier's goods delivery (incoming shipments) is sorted immediately upon entering the cross-docking system and organized according to the demand, i.e. according to the pre-received orders from the points of sale (customers). Thus formed outgoing shipments are loaded directly onto delivery vehicles and delivered to the customers. The simplified functioning of the crossdocking system is presented by Scheme 1 .

It should be noted that the cross-docking system requires significant initial investments and high level of coordination of the included subjects:

- Manufacturers (suppliers), distributers (and/or 3PL operators), and the points of sale (customers) have to be connected by the information and communication system which allows standardization and real-time exchange of data.

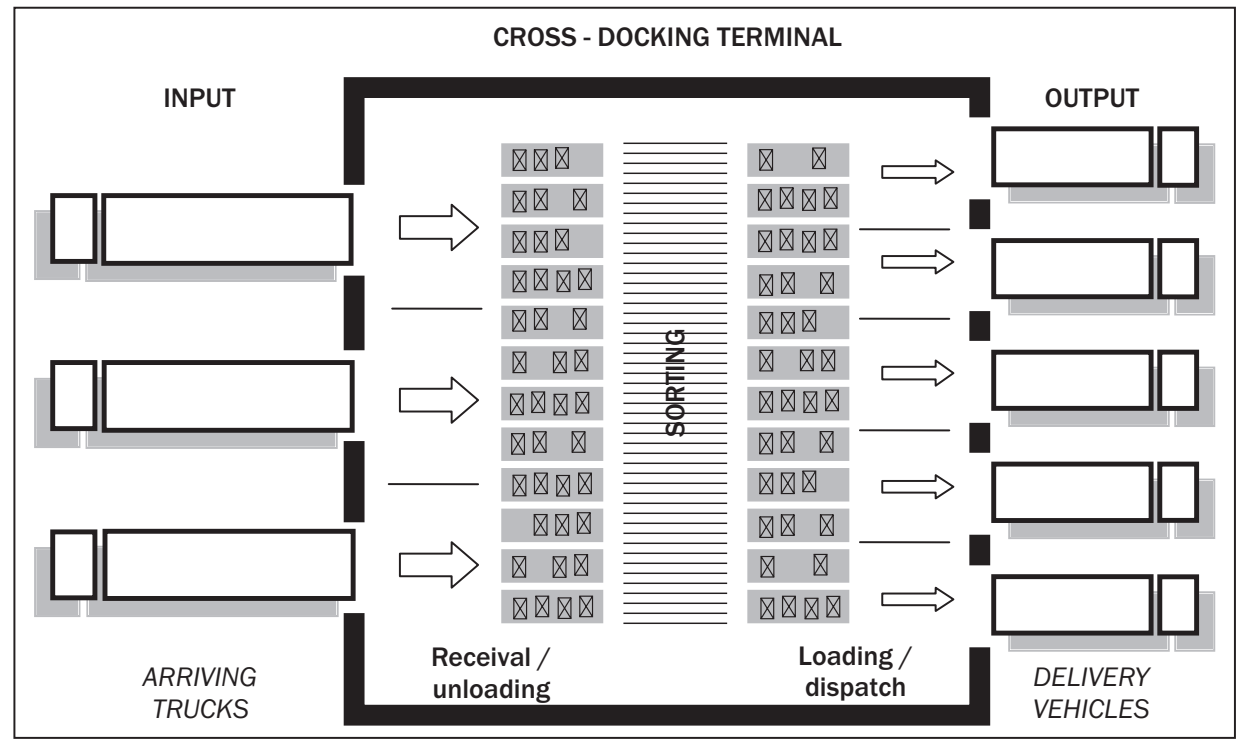

Scheme 1 - Cross-docking system 
- The quantity and frequency of the shipments has to be sufficient in order to allow optimal usage of the transport capacities of the vehicles.

- Constant exchange of information about orders and shipments needs to be provided.

\subsection{Introduction of the cross-docking system in the distribution network}

The cross-docking (CD) terminal managed by the 3PL operator is positioned at $\mathrm{CCG}^{4}$, where the total logistic infrastructure is available, and from the aspect of target segment of the distribution network represents the optimal location. The goods can be received from LDC at locations Ljubljana (1), Munich (2) and Zagreb (4), i.e. dispatched to the points of sale in the cities of Vienna (1), Bratislava (2) and Budapest (3). The receipt of goods at LDC, delivery to the CD terminal, and delivery to the points of sale is also carried out by the same 3PL operator. The unit transport delivery costs to the $C D$ terminal and the delivery to the points of sale are lower because of the possibility of shipment consolidation on the mentioned transport relations [7].

Because of the introduction of the cross-docking system, the transport costs from LDC at locations 1 , 2 and 4 to CD terminal, from CD terminal to the points of sales in cities 1, 2 and 3, as well as cross-docking operative costs are added to the function of objective of the mathematical model:
(3) $+\sum y t_{i} \cdot y_{i}+\sum x t_{j} \cdot x_{j}+c \cdot \sum y_{i}$ for

$i \in\{1,2,4\}, j \in\{1,2,3\}$

with additional condition:

$\sum y_{i}=\sum x_{j} \quad$ for $\quad i \in\{1,2,4\}, j \in\{1,2,3\}$

where:

$y t_{i}=$ unit cost of transport from LDC at location $i$ to $\mathrm{CD}$ terminal, constant ( $€ /$ palette);

$y_{i}=$ quantity of goods delivered from LDC at location $i$ to $\mathrm{CD}$ terminal, continuous variable (palette);

$x t_{j}=$ unit transport cost from CD terminal to points of sale in city $j$, constant $(€ /$ palette);

$x_{j}=$ quantity of goods delivered from CD terminal to points of sale in city $j$, continuous variable (palette);

$c=$ unit operative cost of cross-docking, constant (€/palette).

The solution of the distribution network with the cross-docking system, obtained by the application of the same software tools on the mathematical model has been graphically presented in Figure 2.

\subsection{Features of the new solution}

The graphical presentation (cf. Figure 2) shows the following features of the new solution (distribution network solution with cross docking):

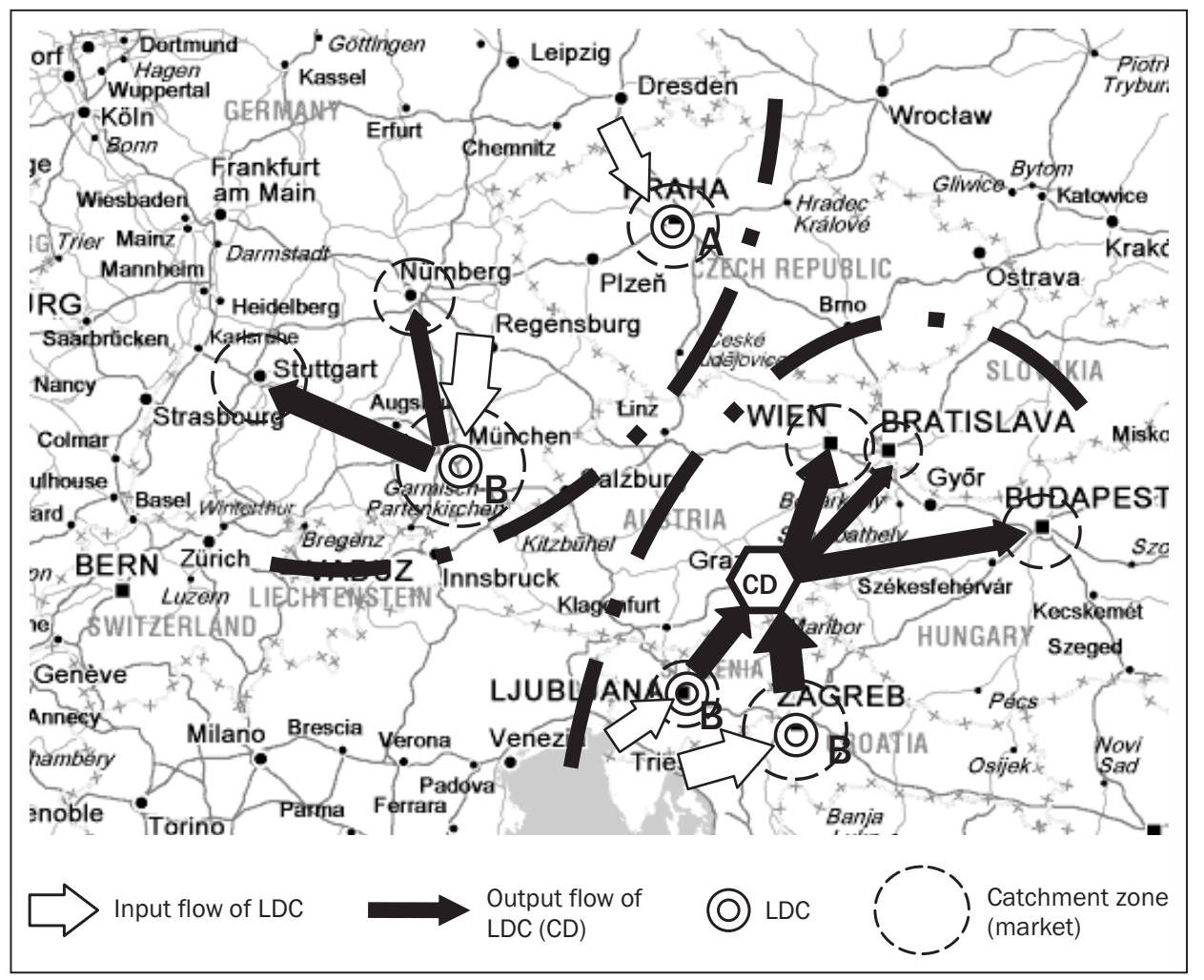

Figure 2 - Graphical presentation of the distribution network solution with cross-docking system

Source: developed by the authors using a car map as model, URL: http//www.viamichelin.com 
- LDCs have been opened at all four locations: type A in Prague, i.e. type B in Ljubljana, Munich and Zagreb.

- The distribution network is divided into two segments which are not interdependent:

1. Northern part, consisting of the markets of Munich, Nurnberg, Prague and Stuttgart, with the supply taking exclusively the northern route, via the Port of Hamburg. The goods are delivered to the points of sale from the LDS open in Munich and Prague;

2. Southern part, consisting of the markets of Vienna, Bratislava, Budapest, Ljubljana and Zagreb being supplied exclusively by the southern route, via the port of Koper for the LDC open in Ljubljana and via the Port of Rijeka for the LDC open in Zagreb.

- The CD terminal is positioned in the southern part, and supplies the markets of Vienna, Bratislava and Budapest. The goods arrive from LDCs in Ljubljana and Zagreb.

- The consolidation of shipments through the cross-docking system reduces the cost of goods delivery to the points of sale on the markets of Vienna, Bratislava and Budapest.

\section{ANALYSIS OF THE NEW SOLUTION}

The analysis of the new solution (distribution network solution with cross docking) has been carried out in the same manner as of the initial solution. In terms of logistic costs, the results of the analysis (cf. Table 2) show two main effects.

First effect of the new solution is overall reduction of the total logistic costs by $€ 13,610$ i.e. by $4 \%$ com- pared to the initial solution (new solution: €327,360; initial solution: €340,970).

Second effect of the new solution is a different structure of the logistic costs, as presented in Graph 1. There is an increase of the total costs of infrastructure, equipment and operation of LDCs plus the additional operative cost of cross-docking, while there is a reduction of the total transport costs.

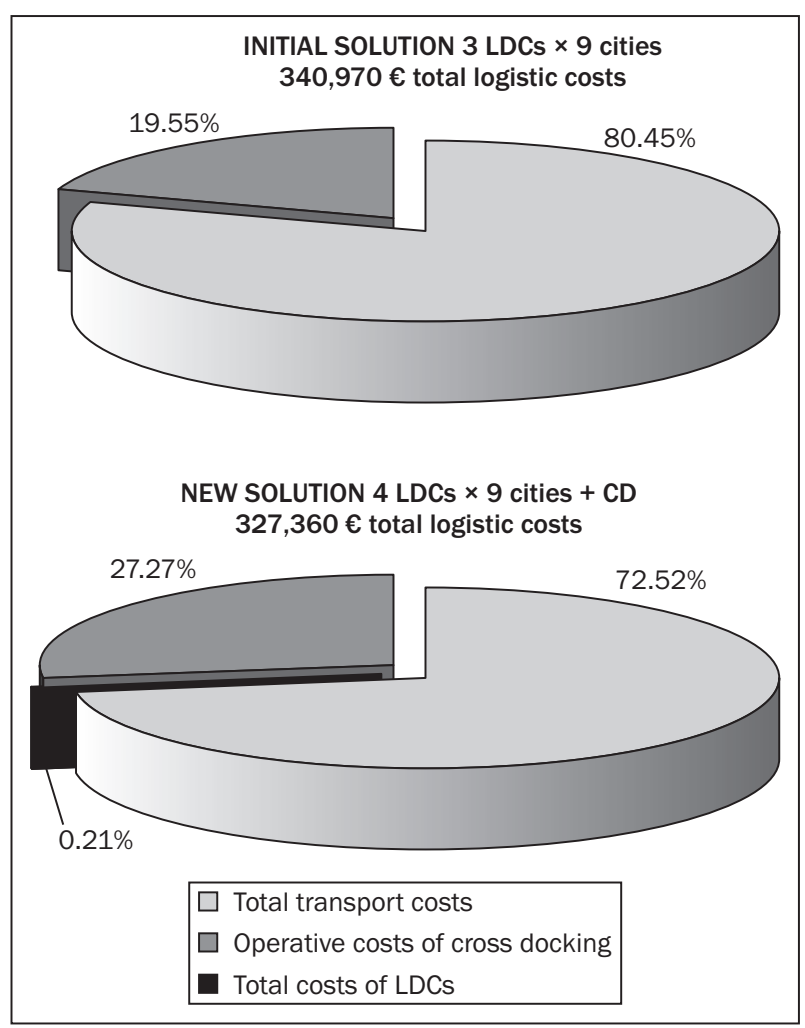

Graph 1 - Structure of the logistic costs

Source: data from Table 1 and Table 2

Table 2 - Analysis of the distribution network solution with cross docking

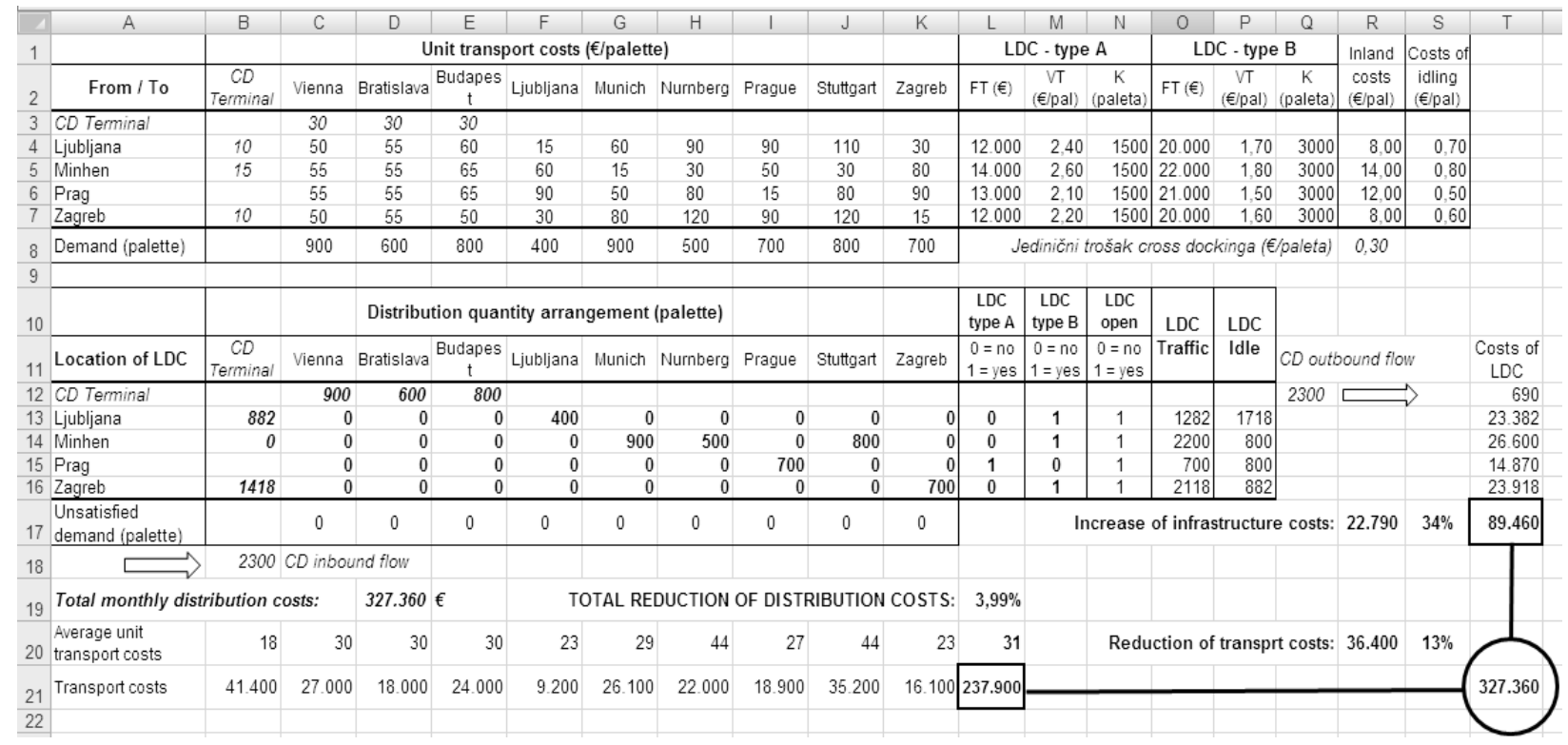




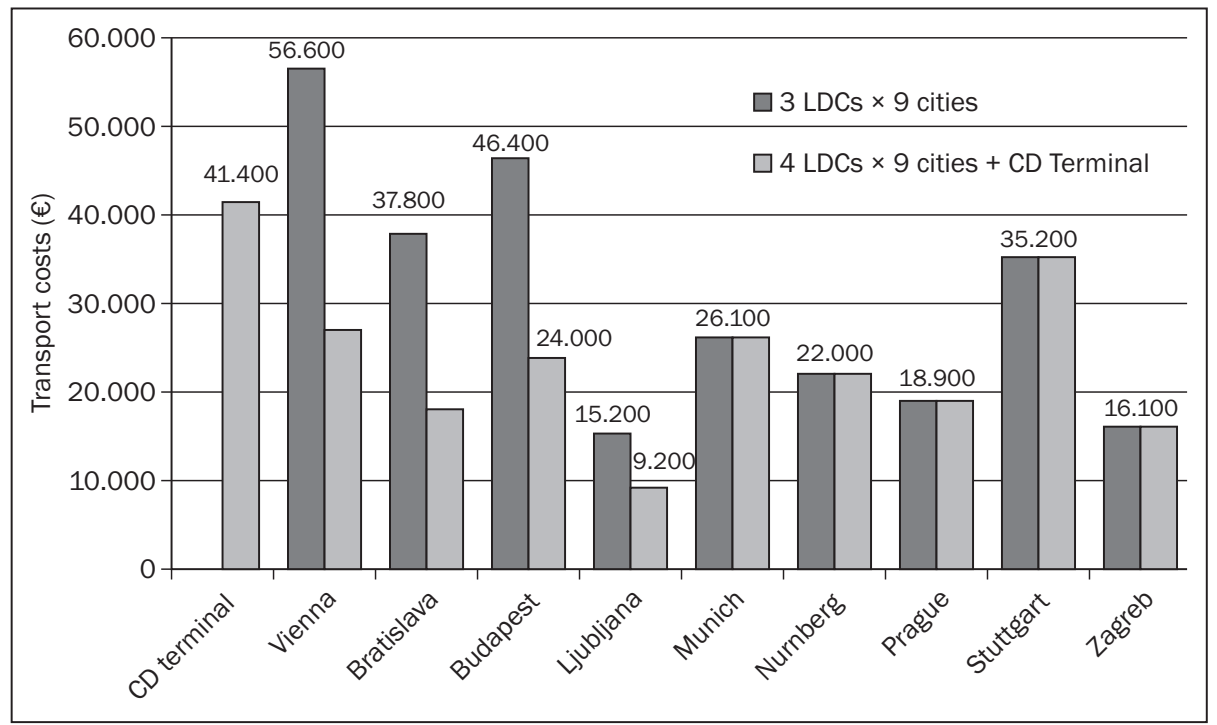

Graph 2 - Comparison of transport costs

Source: data from Table 1 and Table 2

\section{QUANTIFICATION OF IMPROVEMENTS}

Beside the overall reduction of the total logistic costs as a common objective, the application of logistic outsourcing has given certain measurable outcome reflected in the particular improvement elements achieved, which can be quantified by comparing data from Table 2 (new solution) against Table 1 (initial solution).

Total transport cost of the distribution network (delivery of goods to LDCs, i.e. to CD terminals and delivery of goods from LDCs, i.e. from CD terminals to the points of sale) was reduced by $€ 36,400$ i.e. by $13 \%$ compared to the initial solution (cf. Graph 2).

Total costs of infrastructure (fixed and variable costs of LDCs increased by operative costs of crossdocking) have been increased by $€ 22,790$ i.e. by $34 \%$ compared to the initial solution (cf. Graph 3).

Total traffic at the level of the distribution network has been increased by the realized traffic of the $C D$

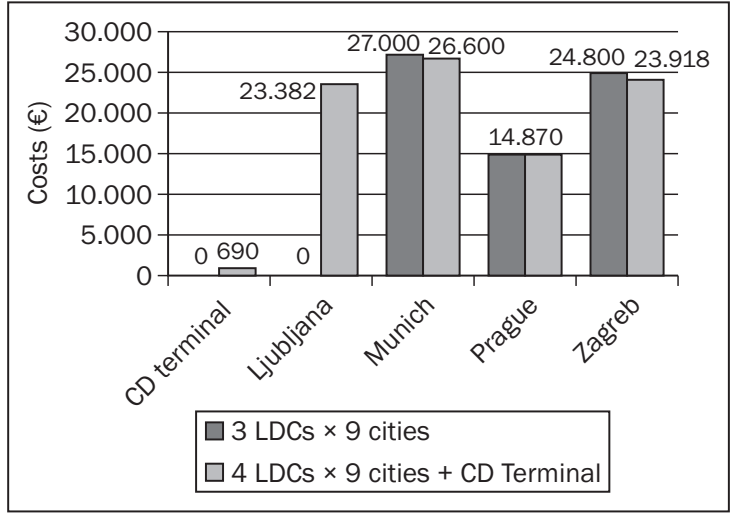

Graph 3 - Comparison of infrastructure costs

Source: data from Table 1 and Table 2 terminal, and the division of traffic between the LDCs has been changed (cf. Graph 4).

\section{CONCLUSION}

In compliance with the distributer's task the function of objective, constants, variables and conditions of the logistic problem have been defined. Before developing a mathematical model, the solubility of the problem has been determined. The mathematical description of the functional characteristics of the distribution network system elements, their interactions and given conditions (restrictions) yield a high-levelsimilarity mathematical model, which, for the needs of solving the problems of the set task, allows a simulation of the functioning of the real distribution network system.

In order to optimize the obtained solution of the distribution network (logistic problem) logistic out-

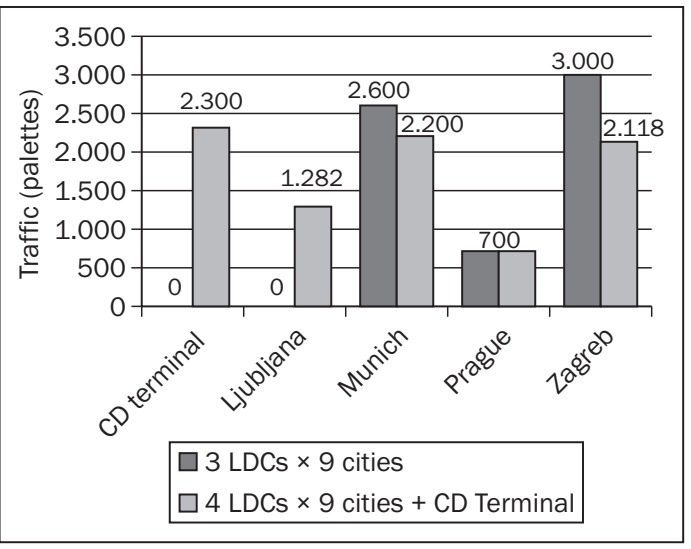

Graph 4 - Comparison of LDC traffic (and $C D$ terminal traffic)

Source: data from Table 1 and Table 2 
sourcing has been applied. The optimized solution of the distribution network with the cross-docking system has been obtained by applying the MS Excel software tools Solver on the mathematical model. In order to quantify the improvement elements, the results of the analysis of the logistic costs of the distribution network before and after applying the logistic outsourcing have been compared (introduction of the cross-docking system). The quantitative changes, apart from the distribution of traffic per LDCs, i.e. improvement regarding the costs of distribution, have been also reflected in the geographic arrangement of distribution, i.e. change of the transport routes of the goods flows. The introduction of the cross-docking system has been said to have pushed the spatial factor (transport distances) into the background, and the logistic outsourcing, i.e. the possibility of optimizing the supply chain by introducing the 3PL operator into the respective segment of the distribution network has become the dominant factor in designing of the distribution network.

\section{Dr. SC. ČEDOMIR IVAKOVIĆ}

E-mail: cedomir.ivakovic@fpz.hr

Sveučilište u Zagrebu, Fakultet prometnih znanosti

Vukelićeva 4, 10000 Zagreb, Republika Hrvatska

\section{Dr. Sc. RATKO STANKOVIĆ}

E-mail: stankovic.zagreb@transadria.hr

Transadria d.d., Robni terminali Žitnjak

Slavonska avenija 52, 10132 Zagreb, Republika Hrvatska

Dr. sc. MARIO ŠAFRAN

E-mail: mario.safran@fpz.hr

Sveučilište u Zagrebu, Fakultet prometnih znanosti

Vukelićeva 4, 10000 Zagreb, Republika Hrvatska

\section{SAŽETAK}

\section{OPTIMIZACIJA DISTRIBUCIJSKE MREŽE PRIMJENOM LOGISTIČKOG OUTSOURCING-A}

Problem oblikovanja distribucijske mreže proizlazi iz potrebe usklađenja obilježja efikasnosti i efektivnosti opskrbnog lanca s konkurentnom strategijom tvrtke. U tom smislu, prikazana je (na matematičkom modelu) mogućnost optimizacije distribucijske mreže primjenom logističkoga outsourcinga. Optimizacija je provedena primjenom MS Excel programskog alata Solver. Rezultati provedene analize pokazali su da prostor za smanjenje troškova distribucije prvenstveno treba tražiti u domeni transporta, u ciljnom segmentu distribucijske mreže. Elementi poboljšanja postignuti su outsourcingom dijela opskrbnog lanca, tj. uvođenjem sustava cross-dockinga kojim upravlja vanjski dobavljač logističkih usluga. Kvantitativne promjene, osim preraspodjele prometa logističko-distribucijskih centara i smanjenja logističkih troškova, očitovale su se i u geografskom rasporedu distribucije. Dominantan utjecaj na oblikovanje distribucijske mreže pritom je imao logistički outsourcing.

\section{KLUČNE RIJEČI}

distribucijska mreža, optimizacija, logistički outsourcing

\section{REFERENCES}

1. The smallest transport unit is one palette, which means that either no or one and several palettes can be delivered into LDC, or from LDC to a city.

2. Provider of third party logistic services.

3. As a rule, the goods do not spend more than 12 hours at the cross-docking terminal.

4. Cargo Center Graz, a LDC for south-eastern Europe, Iocated in Austria, near Graz.

\section{LITERATURE}

[1] Chopra, S., Meindl, P.: Supply Chain Management, Pearson Education Inc., New Jersey, 2004

[2] Simchi-Levi, D., Kaminsky, P., Simchi-Levi, E.: Managing the Supply Chain, McGraw - Hill, New York, 2004

[3] Shapiro, J. F.: Modeling the Supply Chain, Wadsworth Group, Thomson Learning Inc., Duxbury, 2001

[4] International Chamber of Commerce: INCOTERMS 2000, HGK, Zagreb, 1999.

[5] Ivaković, Č., Šafran, M., Rogić, K.: Logistics as Element of Improvements in Storage, Distribution and Transportation of Goods, Journal Promet, Traffic - Traffico, No. 4, volumen 12, Faculty of Transport and Traffic Sciences, Portorož, Trieste, Zagreb, 2000, pp. 157-162

[6] Langevin A., Riopel D.: Logistic Systems - Design and Optimization, New York, 2005

[7] Stanković, R., Ivaković, Č., Šafran, M.: Transformacija robnih tokova u strukturi opskrbnog lanca, Proceedings (CD), Međunarodnog znanstveno-stručnog savjetovanja Znanost i razvitak prometa 2008, Rovinj, 16 - 18 April 2008 